\title{
Partisipasi Pemilih Disabilitas dalam Pemilihan Kepala Daerah (Pilkada) Kabupaten Kudus Tahun 2018
}

\author{
Umi Qodarsasi \\ IAIN Kudus, Kudus, Indonesia \\ umiqodarsasi@gmail.com
}

\begin{abstract}
The direct election of regional heads is a new mechanism in democracy in Indonesia where the people in a region directly elect their regional heads. It is hoped that the public will better understand the regional head candidates and choose candidates whose vision and mission is in accordance with regional needs. In the Kudus Regency Regional Election held on June 27, 2018, voter participation in this election was quite significant, amounting to $84.26 \%$. But the disability voter participation is relatively low, that is, only $0,131 \%$ from the total of voter. This study aims to identify the lack of disability participation in local elections, forms of disability political participation, and supporting factors disability participation. This research applies descriptive qualitative research method with the political participation of disability analytical framework. The data collection techniques in this qualitative study using primary and secondary data. For primary data, researchers will conduct in-depth interviews of institutions related to the holding of the elections and will also be conducted with disability voters in Kudus Regency, both those registered as Permanent Voter Lists (DPT) and those who have not participated in the elections. As for secondary data, researchers conducted a literature review.
\end{abstract}

Keywords: Political Participation; People With Disability; Regional Election 


\begin{abstract}
Abstrak
Pemilihan kepala daerah secara langsung merupakan mekanisme baru dalam demokrasi di Indonesia dimana rakyat di suatu daerah memilih kepala daerahnya secara langsung. Diharapkan masyarakat lebih memahami calon kepala daerah dan memilih calon yang visi dan misinya sesuai dengan kebutuhan daerah. Pada Pilkada Kabupaten Kudus yang diselenggarakan pada 27 Juni 2018, partisipasi pemilih dalam pilkada ini cukup signifikan, yaitu sebesar $84,26 \%$. Namun partisipasi pemilih disabilitas relatif rendah, yakni hanya $0,131 \%$ dari total pemilih. Penelitian ini bertujuan untuk mengidentifikasi kurangnya partisipasi disabilitas dalam pemilihan kepala daerah, bentuk partisipasi politik disabilitas, dan faktor pendukung partisipasi disabilitas. Penelitian ini menggunakan metode penelitian deskriptif kualitatif dengan kerangka analisis partisipasi politik disabilitas. Teknik pengumpulan data dalam penelitian kualitatif ini menggunakan data primer dan data sekunder. Untuk data primer, peneliti akan melakukan wawancara mendalam terhadap instansi yang terkait dengan penyelenggaraan pilkada dan juga akan dilakukan terhadap pemilih disabilitas di Kabupaten Kudus, baik yang terdaftar sebagai Daftar Pemilih Tetap (DPT) maupun yang belum mengikuti pemilukada. pemilu. Sedangkan untuk data sekunder, peneliti melakukan studi pustaka.
\end{abstract}

Kata kunci: Partisipasi Politik; Penyandang Disabilitas; Pemilihan Kepala Daerah (Pilkada)

\title{
A. Pendahuluan
}

Pemilihan kepala daerah secara langsung ini menjadi mekanisme baru dalam demokrasi di Indonesia di mana masyarakat di suatu daerah memilih langsung kepala daerahnya. Hal ini diharapkan agar masyarakat lebih memahami kandidat kepala daerah dan memilih kandidat yang visi misinya sesuai dengan kebutuhan daerah. Dengan adanya pilkada ini berarti bahwa partisipasi politik masyarakat menjadi semakin luas. Kesempatan ini hendaknya disertai dengan pendidikan politik kepada masyarakat sehingga timbul kesadaran politik yang akan berdampak positif pada terwujudnya kepemimpinan daerah yang mengemban amanah rakyat dengan baik.

Pada Pemilihan Kepala Daerah (Pilkada) Kabupaten Kudus yang diselenggarakan pada tanggal 27 Juni 2018, partisipasi pemilih dalam pilkada ini cukup signifikan, yaitu sebesar 84,26\%. Pilkada Kabupaten Kudus ini bertujuan untuk memilih Gubernur/Wakil Gubernur serta bupati/Wakil Bupati. Angka partisipasi ini dapat menjadi salah satu indikator meningkatnya kesadaran pemilih dalam memberikan hak suaranya dalam memilih pemimpin. Kesadaran politik diawali dari kesadaran pemilih bahwa satu suara mereka akan sangat menentukan bagaimana kehidupan bermasyarakat 
di kemudian hari. Ketika yang terpilih adalah pemimpin yang amanah, maka rakyat akan hidup dalam kesejahteraan dan kemakmuran. Sebaliknya, jika pemimpin yang terpilih tidak amanah, maka tatanan kehidupan masyarakat juga menjadi tidak baik. Dalam pemilihan langsung, baik Pemilu maupun Pilkada, legitimasi dari rakyat sangat diperlukan oleh calon pemimpin. Jika pemimpin terpilih menjalankan amanah dengan baik, maka legitimasi rakyat terhadap pemimpin tersebut akan naik. Sebaliknya, jika pemimpin terpilih tidak menjalankan janji-janji kampanye, maka legitimasi rakyat akan turun.

Salah satu indikator keberhasilan penyelenggaraan Pemilu atau Pilkada adalah terlayaninya disabilitas dalam Pilkada. Pada Pilkada dan Pemilu tahun 2014, Komisi Nasional Hak Asasi Manusia (Komnas HAM) menemukan berbagai kasus penyelenggaraan pemilu di berbagai daerah kurang ramah terhadap kelompok disabilitas. Walaupun hak politik difabel telah tertuang dalam Undang-Undang No. 19 tahun 2011, namun penyandang disabilitas belum terakomodasi secara maksimal, pemerintah dinilai tidak siap dalam menyelenggarakan pemilu yang ramah disabilitas. Hal ini menyebabkan partisipasi disabilitas menjadi rendah. Meskipun begitu, Komisi Pemilihan Umum (KPU) sebagai penyelenggara berupaya untuk memenuhi hak politik penyandang disabilitas, misalnya dengan mempersiapkan kertas suara untuk penyandang tuna netra dan menyediakan bahasa isyarat dalam siaran debat calon presiden (Jutaan Penyandang Disabilitas Absen dalam Pemilu dan Pilkada 2018).

Hak politik disabilitas kembali diatur melalui Undang-Undang Nomor 8/2016 tentang penyandang disabilitas. Hak politik penyandang disabilitas di antaranya hak memilih dan dipilih dalam jabatan publik, menyalurkan aspirasi politik, memilih partai politik, serta membentuk organisasi. Hak politik lainnya adalah berperan serta secara aktif dalam sistem pemilihan umum pada semua tahap penyelenggaraan, seperti menjadi pengawas, dan mengikuti pendataan pemilih. KPU membagi penyandang disabilitas menjadi lima kategori, yaitu tunadaksa, tunanetra, tunarungu/tunawicara, tunagrahita, dan disabilitas lainnya (Lahirnya Undang-Undang Republik Indonesia Nomor 8 Tahun 2016 dan Undang-Undang Republik Indonesia Nomor 7 Tahun 2017 Bagi Penyandang Disabilitas 2017). Dengan angka partisipasi politik yang tinggi pada Pilkada Kabupaten Kudus, yaitu 84,26\%, maka perlu untuk melihat partisipasi politik penyandang disabilitas dalam Pilkada Kabupaten Kudus 2018.

Penelitian serupa terkait dengan partisipasi disabilitas dalam Pemilu telah ditulis oleh Zuli Kasmanto dan Santi Nurjannah dalam penelitian yang berjudul "Strategi KPUD Lamongan dalam Meningkatkan Partisipasi pemilih Penyandang Disabilitas di Kabupaten Lamongan pada Pemilu Serentak 2019”. Peelitian ini mengkaji strategi upaya KPUD Lamongan dalam meningkatkan partisipasi disabilitas, antara lain dengan 
cara penguatan kelembagaan, pembentukan relawan demokrasi, serta strategi sosialisasi. Penelitian ini juga mengkaji faktor pendukung dan penghambat dalam implementasi strategi tersebut (Kusmawanto and Nurjannah 2021).

Perbedaan penelitian ini dari penelitian di atas di antaranya adalah lingkup penelitian dan fokus analisis masalah. Peneliti mengkaji partisipasi disabilitas dalam lingkup pemilihan yang lebih kecil, yaitu Pilkada Kabupaten Kudus Tahun 2018. Kemudian, fokus analisis masalah yang dikaji oleh peneliti adalah faktor yang mempengaruhi partisipasi politik penyandang disabilitas dalam Pilkada dengan menggali berbagai informasi dari penyandang disabilitas, baik yang tergabung dalam Forum Komunikasi Disabilitas Kudus (FKDK) maupun tidak. Di samping itu, peneliti selanjutnya mengkaji bagaimana peran dari organisasi politik maupun penyelenggara Pemilu, seperti KPUD Kabupaten Kudus, Bawaslu Kabupaten Kudus, serta DPC beberapa partai politik di Kabupaten Kudus.

Penelitian ini menggunakan metode deskriptif, yaitu pencarian fakta interpretasi yang tepat yang digunakan untuk mempelajari masalah-masalah dalam masyarakat, serta tata cara yang berlaku dalam masyarakat serta situasi-situasi tertentu, termasuk hubungan-hubungan kegiatan, sikap-sikap, pandangan-pandangan, serta proses-proses yang sedang berlangsung dan pengaruh-pengaruh dari suatu fenomena (Mohammad 1998). Penulisan penelitian ini menggunakan "Pendekatan Kualitatif". Menurut Cassel dan Simon, metode kualitatif adalah metode penelitian ilmu sosial yang mendeskripsikan dan menginterpretasikan makna dari gejala yang terjadi dalam konteks sosial secara akurat. Metode kualitatif menekankan pentingnya menggali data-data melalui sumber-sumber tertulis atau terucapkan. Dengan menggunakan metode kualitatif diharapkan peneliti mendapatkan data-data menyeluruh tentang situasi yang dipelajari (Mohammad 1998). Dalam penelitian ini, metode kualitatif ini akan digunakan untuk menganalisis fenomena perilaku pemilih untuk mendongkrak partisipasi pemilih dalam Pemilukada Kabupaten Kudus tahun 2018.

Teknik pengumpulan data dalam penelitian kualitatif ini menggunakan data primer dan sekunder. Untuk data primer, peneliti akan melakukan indepth interview terhadap lembaga-lembaga yang berkaitan dengan penyelenggaraan Pilkada, antara lain KPUD Kabupaten Kudus, partai politik, media massa, dan civil society. Indepth interview juga akan dilakukan kepada pemilih disabilitas di Kabupaten Kudus, baik yang terdaftar sebagai Daftar Pemilih Tetap (DPT) maupun yang belum berpartisipasi dalam Pilkada. Sementara untuk data sekunder, peneliti melakukan telaah kepustakaan dengan cara mengumpulkan data dari buku-buku, literatur, dokumen-dokumen, artikel, jurnal ilmiah dan berbagai sumber yang berhubungan dengan penelitian ini yaitu tentang Partisipasi Pemilih Disabilitas dalam Pemilu Kepala Daerah Kabupaten Kudus 
Tahun 2018. Teknik untuk menganalisa data dalam penelitian ini adalah teknik analisis kualitatif sebagai prosedur penelitian yang menghasilkan data deskriptif.

\section{B. Pembahasan}

Partisipasi politik memiliki pengertian yang beragam. Ada beberapa ahli yang mengungkapkan pendapatnya tentang partisipasi politik. Menurut Ramlan Surbakti yang dimaksud dengan partisipasi politik adalah keikutsertaan warga negara biasa dalam menentukan segala keputusan yang menyangkut atau memengaruhi hidupnya (Surbakti 2007). Herbert McClosky seorang tokoh masalah partisipasi berpendapat bahwa partisipasi politik adalah kegiatan-kegiatan sukarela dari warga masyarakat melalui mana mereka mengambil bagian dalam proses pemilihan penguasa, dan secara langsung atau tidak langsung, dalam proses pembentukan kebijakan umum (Subekti 2014).

Salah satu bentuk yang paling menonjol dari partisipasi politik adalah pemilihan umum, baik sebagai pemilih maupun kandidat yang akan dipilih dalam pemilihan umum. partisipasi dalam bentuk yang luas lagi adalah partisipasi dalam pembuatan kebijakan baik kebijakan besar maupun sederhana, serta berpartisipasi dalam mempengaruhi proses pengambilan kebijakan. Partisipasi politik dalam pemilihan umum tampak dalam beberapa aktivitas, seperti turut serta dalam kampanye politik, melakukan diskusi-diskusi politik, mengikuti berbagai berita politik melalui media massa, serta berpartisipasi dalam mengkritisi kebijakan pemerintah untuk kebaikan seluruh masyarakat. Diskusi-diskusi politik dapat dibangun dalam berbagai forum, baik formal maupun informal. Diskusi politik ini merupakan bagian dari sosialisasi politik yang dilakukan sejak dini di lingkungan keluarga dan masyarakat (Sholichah and Nurchotimah 2020). Eremenko (2014) mengindentifikasi bentuk-bentuk partisipasi politik antara lain voting (memilih); bekerja dalam lembaga penyelenggara pemilu dan berkontribusi dalam kampanye politik; melakukan kontak-kontak dengan pemerintah; mengikuti demonstrasi; bekerja secara informal dalam menyelesaikan permasalahan di masyarakat; serta tergabung dalam asosiasi politik (Fayomi and Adebayo 2017).

Ramlan surbakti mengkategorikan partisipasi politik menjadi dua, yaitu aktif dan pasif. Partisipasi aktif ditunjukkan dengan dengan partisipasi aktif dalam mengajukan ide, gagasan, serta usulan kebijakan yang dikeluarkan oleh pemerintah; memberikan kritik kepada pemerintah jika kebijakan yang dikeluarkan tidak tepat bagi masyarakat; berpartisipasi dalam proses pemilihan pemimpin. Partisipasi politik aktif mencakup baik input maupun output politik. Sementara partisipasi pasif hanya berfokus pada output politik, yaitu dengan hanya menjalankan kebijakan pemerintah saja tanpa melakukan kontrol sosial (Sholichah and Nurchotimah 2020). 
Selanjutnya, Surbakti menyebutkan ada dua variabel penting yang mempengaruhi tinggi rendahnya tingkat partisipasi politik seseorang. Pertama, aspek kesadaran politik terhadap pemerintah (sistem politik). Yang dimaksud dalam kesadaran politik adalah kesadaran hak dan kewajiban warga negara. Misalnya hak politik, hak ekonomi, hak perlindungan hukum, kewajiban ekonomi, kewajiban sosial, dan lain-lain. Kedua, menyangkut bagaimana penilaian serta apresiasi terhadap kebijakan pemerintah dan pelaksanaan pemerintahnya. Sementara itu, faktor yang berdiri sendiri (bukan variabel independen) dipengaruhi oleh faktor-faktor lain, seperti status sosial, afiliasi politik orang tua, dan pengalaman beroganisasi. Yang dimaksud status sosial yaitu kedudukan seseorang berdasarkan keturunan, pendidikan, pekerjaan, dan lain-lain. Selanjutnya status ekonomi yaitu kedudukan seseorang dalam lapisan masyarakat, berdasarkan pemilikan kekayaan. Seseorang yang mempunyai status sosial dan ekonomi tinggi diperkirakan tidak hanya mempunyai pengetahuan politik, akan tetapi memiliki minat serta perhatian pada politik dan kepercayaan terhadap pemerintah (Surbakti 2007).

Penelitian yang dilakukan oleh Tessler, Jamal dan de Miguel (2008), semakin tinggi status sosial ekonomi (didefinisikan dalam hal pendidikan, pendapatan, kelas sosial, pekerjaan), maka semakin besar kemungkinan seseorang untuk berpartisipasi dalam proses politik. Beberapa penelitian juga menunjukkan bahwa usia warga negara bisa menjadi faktor penentu dalam partisipasi politik, yaitu semakin tua seseorang, semakin besar kemungkinan dia untuk berpartisipasi. Partisipasi itu mahal, oleh karena itu hanya mereka yang memiliki cukup sumber daya (uang, waktu, pengetahuan dan koneksi sosial) akan memiliki partisipasi tinggi. Sumber daya ini sangat berkorelasi dengan status sosial ekonomi. Di sisi lain, mereka yang dimobilisasi oleh elit akan berpartisipasi, tapi elit yang memobilisasi mereka mungkin memiliki lebih banyak waktu, uang, pengetahuan dan hubungan sosial pula. Oleh karena itu, penjelasan yang lebih dekat tentang partisipasi adalah tingkat pengetahuan politik individu dan kepentingan politik, apakah individu adalah bagian dari jaringan sosial (agama, klub sepak bola, dll.) dan apakah mereka memiliki rasa keterikatan politik dan rasa kewajiban (Fayomi and Adebayo 2017).

Partisipasi semua warga negara dalam proses politik merupakan landasan demokrasi. Partisipasi politik jelas berakar pada Deklarasi Universal Hak Asasi Manusia dan Kovenan Internasional tentang Hak Sipil dan Politik, yang menyebutkan hak setiap orang untuk partisipasi yang sama dalam urusan publik, hak untuk memilih dan dipilih, dan hak untuk mengakses ke pelayanan publik. Hak ini juga berlaku bagi penyandang disabilitas. Pasal 29 Konvensi Hak-Hak Penyandang Disabilitas (UNCRPD) dengan jelas menyatakan hak-hak penyandang disabilitas untuk 
berpartisipasi dalam kehidupan politik dan publik tanpa diskriminasi dan atas dasar kesetaraan dengan orang lain, dan menyerukan kepada negara pihak untuk menjamin hak-hak tersebut. Ini adalah aspek penting dalam memerangi pengucilan dan ketidaksetaraan, dan tidak meninggalkan siapa pun (Dieye 2019).

Menurut Undang-Undang Nomor 19 Tahun 2011 Tentang Pengesahan Hak-Hak Penyandang Disabilitas, penyandang disabilitas yaitu orang yang memiliki keterbatasan fisik, mental, intelektual atau sensorik dalam jangka waktu lama yang dalam berinteraksi dengan lingkungan dan sikap masyarakatnya dapat menemui hambatan yang menyulitkan untuk berpartisipasi penuh dan efektif berdasarkan kesamaan hak (Undang-Undang Nomor 19 Tahun 2011 Tentang Pengesahan Hak-Hak Penyandang Disabilitas 2011). Ragam dari penyandang disabilitas diatur dalam Pasal 4 Undang-Undang No. 8 Tahun 2016 Tentang Penyandang Disabilitas (Undang-Undang republik Indonesia Nomor 8 Tahun 2016 Tentang Penyandang Disabilitas n.d.) yaitu:

a. Penyandang disabilitas fisik, adalah adalah terganggunya fungsi gerak, antara lain amputasi, lumpuh layuh atau kaku, paraplegi, celebral palsy (CP), akibat stroke, akibat kusta, dan orang kecil.

b. Penyandang disabilitas interlektual adalah adalah terganggunya fungsi pikir karena tingkat kecerdasan di bawah rata-rata, antara lain lambat belajar, disabilitas grahita dan down syndrome.

c. Penyandang disabilitas mental adalah terganggunya fungsi pikir, emosi, dan perilaku, antara lain: 1) psikososial di antaranya skizofrenia, bipolar, depresi, anxietas, dan gangguan kepribadian; 2) disabilitas perkembangan yang berpengaruh pada kemampuan interaksi sosial di antaranya autis dan hiperaktif.

d. Penyandang disabilitas sensorik adalah adalah terganggunya salah satu fungsi dari panca indera, antara lain disabilitas netra, disabilitas rungu, dan/atau disabilitas wicara.

\section{Pemilihan Kepala Daerah (Pilkada) Kabupaten Kudus Tahun 2018}

Pemilihan kepala daerah secara langsung diartikan sebagai pemilihan oleh rakyat secara langsung. Mayoritas suara terbanyak menjadi acuan pemenang pada pilkada tersebut serta pemilihan oleh rakyat secara langsung serentak di adakan seluruh daerah (Budiman 2015).

Hal tersebut yang menjadi alasan dikeluarkannya UU no 32 tahun 2004 Tentang Perubahan Sistem Penyelenggaraan Pemilihan Kepala Daerah secara langsung untuk memperbaiki sistem demokrasi di Indonesia. Konsep otonomi daerah yang dianut oleh 
Indonesia telah memberikan kemungkinan bagi setiap daerah untuk melaksanakan pemilihan kepala daerah dan menentukan pemerintahannya masing-masing. Dalam UU ini, Pilkada belum dimasukkan dalam rezim pemilihan umum (Pemilu). Pilkada pertama kali diselenggarakan pada 1 Juni 2005. Pilkada pertama di Indonesia adalah Pilkada Kabupaten Kutai Kartanegara pada 1 Juni 2005. Sejak berlakunya UU No. 22 Tahun 2007 tentang Penyelenggara Pemilihan Umum, Pilkada dimasukkan dalam rezim Pemilu (Fadjar 2006), sehingga secara resmi bernama Pemilihan Umum Kepala Daerah dan Wakil Kepala Daerah.

Pilkada di Kabupaten Kudus yang diselenggarakan pada 27 Juni 2018 lalu terdiri dari pemilihan Gubernur-Wakil Gubernur Jawa Tengah dan Bupati-Wakil Bupati Kabupaten Kudus. Adapun pasangan calon yang bertanding dalam arena pilkada tersebut adalah sebagai berikut :

Tabel 1. Pasangan Calon Gubernur-Wakil Gubernur Jawa Tengah

\begin{tabular}{|c|c|c|c|c|c|}
\hline No & \multicolumn{2}{|c|}{ Pasangan Calon } & Partai & $\begin{array}{c}\text { Jumlah } \\
\text { Kursi }\end{array}$ & Visi \\
\hline \multirow[b]{2}{*}{1} & $\begin{array}{l}\text { Ganjar } \\
\text { pranowo } \\
\text { (Kader PDI- } \\
\text { P) }\end{array}$ & $\begin{array}{l}\text { Taj Yasin } \\
\text { Maimoen } \\
\text { (Kader PPP) }\end{array}$ & \multirow{2}{*}{$\begin{array}{l}\text { PDI-P } \\
\text { Demokrat } \\
\text { Nasdem } \\
\text { PPP } \\
\text { Golkar }\end{array}$} & \multirow[t]{2}{*}{$58 / 100$} & \multirow{2}{*}{$\begin{array}{l}\text { "Menuju Jawa } \\
\text { Tengah Sejahtera dan } \\
\text { Berdikari; Mboten } \\
\text { Korupsi, Mboten } \\
\text { Ngapusi (Tidak } \\
\text { Korupsi dan Tidak } \\
\text { Membohongi)." }\end{array}$} \\
\hline & $\begin{array}{l}\text { Gubernur } \\
\text { Jawa Tengah } \\
(2013-2018)\end{array}$ & $\begin{array}{l}\text { Anggota } \\
\text { DPRD Jawa } \\
\text { Tengah } \\
(2014-2019)\end{array}$ & & & \\
\hline \multirow{2}{*}{2} & $\begin{array}{l}\text { Sudirman } \\
\text { Said (Non- } \\
\text { Partai) }\end{array}$ & $\begin{array}{l}\text { Ida Fauziyah } \\
\text { (Kader PKB) }\end{array}$ & \multirow{2}{*}{$\begin{array}{l}\text { Gerindra } \\
\text { PKS } \\
\text { PAN } \\
\text { PKB }\end{array}$} & \multirow[t]{2}{*}{$42 / 100$} & \multirow{2}{*}{$\begin{array}{l}\text { "Membangun Jateng } \\
\text { Mukti Bareng } \\
\text { Mencapai Kehidupan } \\
\text { Warga Jawa Tengah } \\
\text { yang Adil, Sejahtera, } \\
\text { Maju, dan Beradab. }\end{array}$} \\
\hline & $\begin{array}{l}\text { Menteri } \\
\text { ESDM } \\
(2014-2016)\end{array}$ & $\begin{array}{l}\text { Anggota } \\
\text { DPR-RI } \\
(2014-2019)\end{array}$ & & & \\
\hline
\end{tabular}

Sumber: KPUD Kab. Kudus 
Tabel 2. Pasangan Calon Bupati - Wakil Bupati Kabupaten Kudus 2018

\begin{tabular}{|c|c|c|c|c|}
\hline $\begin{array}{c}\text { No } \\
\text { Urut }\end{array}$ & \multicolumn{2}{|c|}{ Pasangan Calon } & $\begin{array}{c}\text { Partai } \\
\text { Penousung }\end{array}$ & Visi \\
\hline \multirow[b]{2}{*}{1} & Masan, S.E., MM. & $\begin{array}{l}\text { Drs. H. Noor Yasin, } \\
\text { MM. }\end{array}$ & \multirow{2}{*}{$\begin{array}{l}\text { Demokrat } \\
\text { PAN } \\
\text { Golkar } \\
\text { PDI-P }\end{array}$} & \multirow{2}{*}{$\begin{array}{l}\text { "Bersama } \\
\text { Membangun } \\
\text { Kudus Lebih } \\
\text { Baik." }\end{array}$} \\
\hline & $\begin{array}{l}\text { Calon Bupati : } \\
\text { Anggota } \quad \text { DPRD } \\
\text { Kudus Periode 2014- } \\
2019\end{array}$ & $\begin{array}{ll}\text { Calon Wakil Bupati : } \\
\text { Sekretaris } & \text { Daerah } \\
\text { Kudus } & (2012- \\
\text { sekarang) } & \end{array}$ & & \\
\hline \multirow[b]{2}{*}{2} & $\begin{array}{l}\text { H. Noor Hartoyo, } \\
\text { SH. }\end{array}$ & Junaidi, SH. & \multirow[t]{2}{*}{ Independen } & \multirow{2}{*}{$\begin{array}{l}\text { "Terwujudnya } \\
\text { Seluruh } \\
\text { Masyarakat } \\
\text { Kudus yang } \\
\text { Berperadaban dan } \\
\text { Sejahtera." }\end{array}$} \\
\hline & $\begin{array}{l}\text { Calon Bupati : Wakil } \\
\text { Ketua DPRD Kudus } \\
\text { Periode 2009-2014. }\end{array}$ & $\begin{array}{l}\text { Calon Wakil Bupati : } \\
\text { Staf Pemerintahan } \\
\text { Kelurahan Mlati } \\
\text { Norowito Kudus }\end{array}$ & & \\
\hline \multirow[b]{2}{*}{3} & Hj. Sri Hartini, ST. & $\begin{array}{l}\text { H. Setia Budi } \\
\text { Wibowo, S.Ag., } \\
\text { MM. }\end{array}$ & \multirow[t]{2}{*}{$\begin{array}{c}\text { PBB } \\
\text { PKS } \\
\text { Gerindra }\end{array}$} & \multirow[t]{2}{*}{$\begin{array}{l}\text { "Kudus Unggu } \\
\text { Mumpuni." }\end{array}$} \\
\hline & $\begin{array}{lr}\text { Calon } & \text { Bupati : } \\
\text { Anggota } & \text { DPRD } \\
\text { Propinsi } & \text { Jawa } \\
\text { Tengah } & \text { Periode } \\
\text { 2009-2014 } & \end{array}$ & $\begin{array}{l}\text { Calon Wakil Bupati : } \\
\text { Anggota DPRD } \\
\text { Kudus Periode 2014- } \\
2019 .\end{array}$ & & \\
\hline \multirow[b]{2}{*}{4} & H. Akhwan, S.H. & $\begin{array}{l}\text { H. Hadi Sucipto, } \\
\text { S.Pd., MM. }\end{array}$ & \multirow[t]{2}{*}{ Independen } & \multirow{2}{*}{$\begin{array}{l}\text { "Terwujudnya } \\
\text { Kudus Makmur } \\
\text { Bermatabat." }\end{array}$} \\
\hline & $\begin{array}{lr}\text { Calon } & \text { Bupati : } \\
\text { Anggota } & \text { DPRD } \\
\text { Propinsi } & \text { Jawa } \\
\text { Tengah } & \text { Periode } \\
\text { 2004-2009 } & \end{array}$ & $\begin{array}{l}\text { Calon Wakil Bupati : } \\
\text { Kepala Dinas } \\
\text { Perindustrian, } \\
\text { Koperasi, UMKM } \\
\text { Kudus Tahun } 2015 .\end{array}$ & & \\
\hline \multirow[b]{2}{*}{5} & $\begin{array}{l}\text { Ir. H. Muhammad } \\
\text { Tamzil, MT. }\end{array}$ & $\begin{array}{l}\text { HM Hartopo, ST, } \\
\text { MM, MH. }\end{array}$ & \multirow{2}{*}{$\begin{array}{l}\text { Hanura } \\
\text { PPP } \\
\text { PKB }\end{array}$} & \multirow{2}{*}{$\begin{array}{l}\text { "Kudus Bangkit } \\
\text { Menuju } \\
\text { Kabupaten } \\
\text { Modern, Religius, } \\
\text { dan Sejahtera." }\end{array}$} \\
\hline & $\begin{array}{lr}\text { Calon } & \text { Bupati } \\
\text { Bupati } & \text { Kudus } \\
\text { Periode } & 2003-2008\end{array}$ & $\begin{array}{l}\text { Calon Wakil Bupati : } \\
\text { Anggota DPRD } \\
\text { Kudus Periode 2014- } \\
2019 .\end{array}$ & & \\
\hline
\end{tabular}

Sumber: KPUD Kab. Kudus

Jumlah DPT yang menggunakan hak pilihnya adalah sebanyak 520.589 jiwa dengan rincian 473.595 suara sah dan 46.994 suara tidak sah dalam pemilihan Gubernur-Wakil Gubernur Jawa Tengah serta 503.419 suara sah dan 16.891 suara tidak sah dalam pemilihan Bupati-Wakil Bupati Kabupaten Kudus. Suara tidak sah sebagian 
besar diakibatkan oleh kesalahan saat mencoblos di kertas suara. Dalam Pilkada Kabupaten Kudus, KPU menyiapkan tempat pemungutan suara sebanyak 1.491 yang tersebar di 123 desa di seluruh Kabupaten Kudus. Berikut hasil rekapitulasi hasil perolehan suara Pilkada Kabupaten Kudus Tahun 2018 :

Tabel 3. Rincian Perolehan Calon Gubernur dan Wakil Gubernur Jawa Tengah 2018 di Kabupaten Kudus

\begin{tabular}{|l|l|c|}
\hline No & \multicolumn{1}{|c|}{ Nama Pasangan Calon } & $\begin{array}{c}\text { Jumlah } \\
\text { Akhir }\end{array}$ \\
\hline 1 & H. Ganjar Pranowo, SH., MIP. Dan H. Taj Yasin, S.HI, M.Si. & 384.352 \\
\hline 2 & Sudirman Said dan Drs. Ida Fauziyah, M.Si. & 125.243 \\
\hline & Suara Sah & $\mathbf{4 7 3 . 5 9 5}$ \\
\hline & Suara Tidak Sah & 46.994 \\
\hline & Seluruh Suara & $\mathbf{5 2 0 . 5 8 9}$ \\
\hline
\end{tabular}

Sumber: KPUD Kab. Kudus

Tabel 4. Rincian Perolehan Calon Bupati dan Wakil Bupati Kabupaten Kudus Tahun 2018 per Kecamatan

\begin{tabular}{|c|c|c|}
\hline No & Nama Pasangan Calon & Jumlah Akhir \\
\hline 1 & Masan - Noor Yasin & 194.093 \\
\hline 2 & Noor Hartoyo - Junaidi & 7.393 \\
\hline 3 & Sri Hartini - Setia Budi Wibowo & 76.792 \\
\hline 4 & Akhwan - Hadi Sucipto & 11.151 \\
\hline 5 & Muhammad Tamzil - Hartopo & 213.990 \\
\hline & Suara Sah & $\mathbf{5 0 3 . 4 1 9}$ \\
\hline & Suara Tidak Sah & 18.891 \\
\hline & Seluruh Suara & $\mathbf{5 2 0 . 3 1 0}$ \\
\hline
\end{tabular}

Sumber: KPUD Kab. Kudus

\section{Partisipasi Disabilitas dalam Pilkada Kabupaten Kudus Tahun 2018}

Organisasi Kesehatan Dunia memperkirakan bahwa 15 persen dari populasi dunia kurang lebih dari satu miliar pria, wanita dan anak-anak - memiliki disabilitas. Penyandang disabilitas dapat ditemukan dalam semua kelompok agama, sosial, politik dan ekonomi. Mereka bisa menjadi lahir dengan cacat, atau mereka dapat memperoleh cacat di kemudian hari, karena misalnya melalui kecelakaan, genetik, usia atau konflik bersenjata. Penyandang disabilitas adalah bagian dari masyarakat, mereka adalah orang tua, siswa, pengusaha, atlet, artis, guru, politisi dan banyak lagi. Namun, penyandang 
disabilitas juga termasuk yang komunitas yang didiskriminasi di seluruh dunia. Selama bertahun-tahun, masyarakat di dunia telah menganggap disabilitas sebagai sesuatu yang ditakuti atau dikasihani. Mitos dan stigma negatif tentang penyandang disabilitas seperti keyakinan bahwa mereka tidak mampu membuat kontribusi positif bagi masyarakat. Akibatnya, orang dengan penyandang disabilitas menghadapi hambatan yang signifikan dalam upaya mereka untuk mengakses hak-hak dasar mereka, termasuk hak atas partisipasi politik (Guidelines on Promoting the Political Participation of Persons with Disabilities 2019).

Partisipasi politik disabilitas dalam pemilihan umum seringkali mengalami berbagai kendala. Sejumlah kendala signifikan berdampak negatif terhadap keterlibatan penyandang disabilitas dalam kehidupan politik di antaranya adalah kurangnya akses ke parlemen dan informasi tentang isu-isu politik, dukungan yang tidak memadai, stereotip yang berlaku tentang penyandang disabilitas dan kemungkinan kontribusi mereka terhadap proses politik dan pengambilan keputusan. Ini semua berkontribusi pada pengucilan dan diskrimnasi terhadap penyandang disabilitas. Bagi perempuan penyandang disabilitas itu berarti menghadapi tantangan tambahan, sebagai akibat dari ketidaksetaraan yang terus berlanjut dan diskriminasi berdasarkan gender dan disabilitas. Partisipasi penyandang disabilitas dalam politik, publik dan kehidupan sosial sangat penting untuk melawan stereotip, prasangka dan diskriminasi. Eksklusivitas dalam proses pembuatan kebijakan semakin membuat penyandang disabilitas terpinggirkan. Untuk itu diperlukan upaya untuk memastikan penyandang disabilitas dapat berperan aktif dalam kehidupan sosial dan politik, serta diperlukan kerangka kebijakan yang dapat mengakomodir kelompok tersebut sehingga terwujud masyarakat yang saling menghargai (Guidelines on Promoting the Political Participation of Persons with Disabilities 2019).

Penting bagi penyandang disabilitas untuk terlibat dalam proses politik, salah satunya dengan tergabung melalui partai politik, sehingga ketika duduk di parlemen mereka mempunyai kesempatan untuk memberdayakan penyandang disabilitas baik laki-laki dan perempuan dengan menyuarakan pendapat mereka tentang isu-isu yang penting bagi mereka, dan untuk menjadi pemimpin bagi diri mereka sendiri. Keterlibatan seperti itu juga menciptakan peluang ideal bagi institusi politik untuk menghilangkan hambatan dan menjadi lebih inklusif, dapat diakses, dan benar-benar mewujudkan keterwakilan dalam masyarakat (Guidelines on Promoting the Political Participation of Persons with Disabilities 2019).

Di Indonesia, penyandang disabilitas mempunyai hak politik yang sama dengan warga negara lainnya. Hak politik ini diatur dalam Undang-Undang Nomor 8 Tahun 2016 Pasal 13. Meliputi : a) memilih dan dipilih dalam jabatan publik; b) menyalurkan 
aspirasi politik baik tertulis maupun lisan; c) memilih partai politik dan/atau individu yang menjadi peserta dalam pemilihan umum; d) membentuk, menjadi anggota, dan/atau pengurus organisasi masyarakat dan/atau partai politik; e) membentuk dan bergabung dalam organisasi Penyandang Disabilitas dan untuk mewakili Penyandang Disabilitas pada tingkat lokal, nasional, dan internasional; f) berperan serta secara aktif dalam sistem pemilihan umum pada semua tahap dan/atau bagian penyelenggaraannya; g) memperoleh aksesibilitas pada sarana dan prasarana penyelenggaraan pemilihan umum, pemilihan gubernur, bupati/walikota, dan pemilihan kepala desa atau nama lain; dan h) memperoleh pendidikan politik.

Pasal lain Undang-Undang ini, yaitu pasal 7 dinyatakan "Hak bebas dari stigma untuk Penyandang Disabilitas meliputi hak bebas dari pelecehan, penghinaan, dan pelabelan negatif terkait kondisi disabilitasnya. Dalam pelaksanaan pilkada maupun pemilu, penyandang disabilitas harus diberi ruang partisipasi dan akses politik yang lebih luas sehingga bisa menyalurkan aspirasi politiknya secara maksimal. Tidak boleh ada pembedaan, diskriminasi, atau pengecualian terhadap kelompok disabilitas tertentu, termasuk hak bagi penyandang disabilitas mental untuk masuk dalam daftar pemilih untuk menggunakan hak pilihnya.

KPUD Kabupaten Kudus mencatat jumlah penyandang disabilitas yang terdaftar sebagai DPT pada Pilkada tahun 2018 berjumlah 843 pemilih atau 0,131\% dari seluruh DPT di Kabupaten Kudus, yang terdiri dari disabilitas daksa, disabilitas netra, disabilitas rungu dan tuli, disabilitas mental (ODGJ), dan disabilitas lainnya. Di hari pelaksanaan pilkada, tidak semua DPT disabilitas menggunakan hak pilihnya, dari 843 penyandang disabilitas yang terdaftar sebagai DPT, hanya sebanyak 237 orang yang menggunakan hak pilihnya. Rincian pemilih disabilitas dalam Pilkada ditunjukkan pada tabel di bawah ini :

Tabel 5. Rincian Pemilih Disabilitas dalam Pilkada Kab. Kudus tahun 2018

\begin{tabular}{|c|l|c|c|}
\hline No & \multicolumn{1}{|c|}{ Pemilih Disabilitas } & Jenis Kelamin & Jumlah \\
\hline \multirow{2}{*}{1} & $\begin{array}{l}\text { Penyandang Disabilitas yang } \\
\text { terdaftar DPT }\end{array}$ & Laki-Laki & 420 orang \\
\cline { 3 - 4 } & & Perempuan & 423 orang \\
\cline { 2 - 4 } 2 & $\begin{array}{l}\text { Disabilitas yang Menggunakan } \\
\text { Hak Suara }\end{array}$ & Laki-Laki & 843 orang \\
\cline { 3 - 4 } & & Perempuan & 127 orang \\
\cline { 2 - 4 } & & Total & 237 orang \\
\hline
\end{tabular}

Sumber: KPUD Kab. Kudus 
Jumlah disabilitas yang terdaftar DPT dan yang menggunakan hak suara pada tabel di atas tersebar di 9 Kecamatan di Kabupaten Kudus, yaitu Kecamatan Kaliwungu, Kecamatan Kudus, Kecamatan Undaan, Kecamatan Jati, Kecamatan Jekulo, Kecamatan Mejobo, Kecamatan Bae, Kecamatan Gebog, dan Kecamatan Dawe. Jumlah pemilih yang menggunakan suaranya masih sangat minim dibandingkan dengan jumlah yang terdaftar sebagai DPT. Menurut pandangan ketua Forum Komunikasi Disabilitas Kudus (FKDK), ada beberapa hal yang menjadi sebab masih minimnya partisipasi disabilitas dalam Pilkada, antara lain: tidak semua penyandang disabilitas mempunyai akses menuju lokasi TPS. Tidak semua difabel memiliki kursi roda atau kendaraan (yang dimodifikasi) menuju lokasi TPS, sehingga sulit bagi mereka untuk mencapai lokasi TPS; ada TPS yang masih tidak ramah disabilitas. Misalnya TPS yang berada di ruangruang kelas, sehingga menyulitkan bagi pengguna kursi roda di mana tidak ada keleluasaan di dalam ruangan kelas; tidak semua TPS menyediakan fasilitas kursi roda bagi para difabel karena keterbatasan anggaran. Dan tidak semua TPS menyediakan sarana untuk difabel, misalnya surat suara dengan huruf braille. Hanya TPS tertentu saja yang mengakomodir kelompok difabel ini; ada difabel dengan disabilitas ganda atau parah sehingga tidak memungkinkan untuk hadir di TPS. Sementara KPU belum ada mekanisme mobile TPS sehingga difabel dalam kategori ini harus rela kehilangan suaranya dalam memilih kepala daerah.

Ketua FKDK berharap pada pemilu periode berikutnya, fasilitas bagi penyandang disabilitas harus ditingkatkan lagi sehingga bisa menopang partisipasi politik. Kelompok difabel sendiri menolak anggapan bahwa mereka tidak menggunakan suaranya karena sikap skeptik terhadap pemerintah yang belum dengan maksimal memberikan dukungan bagi difabel. Ketua FKDK sendiri menegaskan alasan dibentuknya FKDK ini adalah sebagai sarana bagi kaum difabel untuk meningkatkan kapasitas diri, mengadvokasi diri dan kelompok, merobohkan stigma negatif masyarakat terhadap difabel, serta membangun networking dengan berbagai pihak baik pemerintah, swasta, NGO maupun lembaga pendidikan untuk kemajuan kelompok difabel.

Pandangan etika politik Islam, ada nilai-nilai yang mengajarkan kesetaraan dalam kehidupan politik. Prinsip-prinsip politik dalam Islam termasuk ruang lingkup kajian antara manusia dengan manusia (hablum minannas) atau yang dikenal dengan prinsip muamalah. Merujuk pada pandangan Abu Zahrah Muhammad, ada beberapa prinsip politik Islam (Surwandono 2017), yaitu :

Kehormatan manusia (karamah insaniyah) : prinsip menghormati dan memuliakan pihak lain apapun kondisi dan atribut yang melekat terhadapnya. Jika dalam kondisi berkompetisi atau bermusuhan maka tidak boleh menghinakan pihak lain. 
Manusia sebagai umat yang satu. Politik Islam membangun hubungan yang integratif bukan konfliktual, menemukan sinergi, bukan memupuk permusuhan. Manusia sebagai khalifah tidak dapat membangun kemakmuran di muka bumi manakala hanya mengandalkan unilateralisme, namun akan mudah tercapai dengan mengandalkan universalisme. Jika timbul perselisihan, maka kembali kepada al-quran sebagai petunjuk.

a. Kerja sama kemanusiaan (ta'awun insani): kerja sama didesain dengan nalar tolong menolong dalam kebaikan dan ketaqwaan, bukan tolong menolong dalam keburukan dan perselisihan.

b. Tasamuh: prinsip untuk menghormati privasi dan kepentingan pihak lain. Islam sangat ramah dengan prinsip non intervensi.

c. Kemerdekaan (hurriyah): hubungan kerja sama dilandasi dengan ikhtiar untuk meningkatkan derajat kemerdekaannya, bukan untuk menggerus kemerdekaan orang lain.

d. Budi baik (fadillah): dalam berpolitik, memberi tidaklah harus dilandasi untuk mendapatkan sesuatu yang lebih banyak. Prinsip fadillah ini merupakan antitesis dari pragmatism yang mewarnai perpolitikan saat ini.

e. Keadilan ('adalah): menjalankan nalar keadilan dalam menjalin interaksi dengan pihak lain. Adil tidak hanya dilihat dari kuantitas saja, tapi juga kualitas.

f. Perlakuan yang sama. Membangun nalar pergaulan antar manusia dengan kesetaraan. Pergaulan dalam Islam mengedepankan prinsip non diskriminasi.

g. Kasih sayang (mawaddah) dan pencegah kerusakan: membangun hubungan yang harmonis dan mengedepankan pencegahan kerusakan menjadi hal yang penting dalam bermuamalah.

Prinsip-prinsip politik Islam ini sangat menjunjung prinsip kesetaraan dan penghormatan terhadap manusia. Penyandang disabilitas juga sebagaimana manusia lainnya yang berhak diperlakukan secara adil dan tanpa diskriminasi. Penyandang disabilitas sangat butuh dukungan dan akses dari pemerintah dan masyarakat sehingga bisa meningkatkan kualitas hidupnya dengan lebih baik, mandiri, dan sustainable. Peminggiran terhadap mereka akan berdampak pada pembunuhan potensi dan rasa percaya dirinya. 


\section{Peran Lembaga Penyelenggara Pilkada dalam Upaya Peningkatan Partisipasi Disabilitas}

Terkait dengan pelayanan terhadap disabilitas, komisioner KPUD Kabupaten Kudus menyatakan sudah berusaha secara maksimal untuk memberikan fasilitas kepada disabilitas supaya bisa ikut berpartisipasi dan memberikan suaranya dalam Pilkada kabupaten Kudus tahun 2018. ${ }^{1}$ KPUD Kudus menjalin kerjasama dengan disabilitas melalui komunitas-komunitas difabel, salah satunya adalah forum Komunikasi Disabilitas Kudus (FKDK). Pelibatan penyandang disabilitas ini dimulai dari sosialisasi tentang Pilkada kepada komunitas ini. Sosialisasi ini diharapkan dapat memberikan pemahaman tentang teknis pencoblosan, seperti : contoh jenis surat suara termasuk yang menggunakan template braille; cara mencoblos supaya suara sah; TPS di setiap desa yang bisa diakses oleh disabilitas. Sebagai salah satu komunitas penggerak, FKDK diharapkan dapat menyebarkan sosialisasi kepada difabel lainnya serta memotivasi untuk berpartisipasi dalam Pilkada.

Pelibatan difabel juga dilakukan oleh KPUD dalam kegiatan penataan logistik Pilkada. KPUD mengundang beberapa perwakilan difabel untuk turut membantu melipat kertas suara. Selain itu difabel juga diikutsertakan dalam acara sosialisasi Pilkada bersama lintas difabel dari difabel daksa, difabel netra, dan difabel rungu wicara. Dalam acara sosialisasi, peserta diberi banyak pembekalan, terutama cara mencoblos yang baik dan benar. Tak luput, penyajian contoh template surat suara bagi pencoblos tunanetra. Lebih dari itu, untuk meningkatkan partisipasi politik penyandang disabilitas di Kabupaten Kudus.

Kelompok difabel juga turut diundang dalam acara debat terbuka calon bupati dan wakil bupati Kudus yang diselenggarakan di Pendopo Kabupaten Kudus. Salah satu materi debat calon bupati dan wakil bupati adalah tentang upaya pemberdayaan penyandang disabilitas di Kudus. Dengan hadirnya kelompok difabel dalam debat ini dapat menjadi bahan pertimbangan bagi mereka untuk menilai paslon mana yang berkeinginan serius untuk memberdayakan penyandang disabilitas di Kudus dan apa yang ditawarkannya. Komunitas difabel di Kudus sedang berjuang untuk mewujudkan Kabupaten Kudus yang inklusif. Melalui debat terbuka ini, mereka dapat menilai pengetahuan dan perhatian paslon pada penyandang disabilitas.

Sementara itu, berdasarkan hasil wawancara dengan komisioner Badan Pengawas Pemilu (Bawaslu) Kabupaten Kudus, upaya untuk meningkatkan partisipasi penyandang disabilitas sebagai pengawas pilkada/pemilu terus dilakukan, terutama dalam kegiatan pengawasan pemilu partisipatif. Salah satu misi Bawaslu adalah

\footnotetext{
${ }^{1}$ Wawancara dengan komisioner KPUD kab. Kudus
} 
mendorong pengawasan partisipatif berbasis masyarakat sipil. Pelibatan masyarakat dalam pengawasan pemilu harus melalui proses sosialisasi, transfer pengetahuan dan keterampilan pengawasan pemilu dari pengawas kepada masyarakat.

Bawaslu Kudus menyertakan penyandang disabilitas dalam sosialisasi pemilu partisipatif. Bawaslu berharap dengan adanya sosialisasi pengawasan partisipatif ini peran penyandang disabilitas menjadi lebih luas, bukan hanya memberikan suara dalam pilkada, akan tetapi juga turut menegakkan pemilu yang bersih di masyarakat. Minimal mereka bisa menjadi agen yang bisa mensosialisasikan pesan pemilu bersih ini kepada komunitas difabel lainnya. Dalam pengawasan pemilu di kecamatan maupun desa, sejauh ini belum ada penyandang difabel yang mendaftarkan diri sebagai pengawas kecamatan maupun desa. Secara regulasi Bawaslu terbuka terhadap perekrutan pengawas dari kelompok difabel. Akan tetapi dari kelompok difabel ini belum ada yang mendaftar, padahal sosialisasi pengawas ini sudah sering dilakukan. Pada waktu sosialisasi, kelompok difabel juga banyak yang hadir. Komisioner menduga kemungkinan ada rasa tidak percaya diri atau keraguan dari kelompok difabel ini untuk mendaftarkan diri. Ke depan diharapkan ada kelompok difabel yang ikut serta menjadi pengawas pemilu dan pilkada, supaya partisipasi mereka bisa lebih luas lagi, bukan hanya sekedar menjadi pemilih, tapi juga turut berpartisipasi dalam penyelenggaraan pilkada atau pemilu.

Partai politik merupakan suprastruktur dalam sistem politik yang mempunyai fungsi strategis, seperti sosialisasi politik, rekrutmen politik, komunikasi politik dan sarana pengatur konflik. ${ }^{2}$ Pada periode pilkada atau pemilu, sosialisasi oleh partai seharusnya tidak hanya dengan tujuan meraup suara, tetapi lebih dari itu untuk meningkatkan kesadaran masyarakat untuk menggunakan hak pilihnya sebaik mungkin. Berdasarkan hasil wawancara dengan Paguyuban Tuli Kudus (Patuku), ada upaya dari salah satu paslon dan parpol pendukungnya untuk memobilisasi suara dari kelompok disabilitas ini. Mobilisasi ini tidak sesuai dengan idealitas parpol. Kegiatan sosialisasi pun dilakukan manakala menjelang pilkada atau pemilu, sehingga sudah bisa dipastikan parpol-parpol ini hanya memenuhi tujuan pragmatis.

Dalam proses rekrutmen politik, berdasarkan hasil wawancara dengan salah satu politisi, beliau mengatakan pada dasarnya parpol sangat terbuka dengan berbagai golongan, termasuk penyandang disabilitas. Sejauh penyandang disabilitas ini mempunyai potensi dan mau mengembangkan kapasistas dirinya. Beliau menjelaskan, untuk dapat menjadi politisi sukses tidaklah bisa didapatkan dalam waktu yang instan. Proses kaderisasi di partai dimulai dalam waktu yang cukup lama untuk melatih

\footnotetext{
${ }^{2}$ Miriam Budiharjo, Dasar-Dasar Ilmu Politik, PT Gramedia Pustaka Utama, Jakarta, 1991, hal. 163
} 
kapasitas kepemimpinan politik. Belaiu mencontohkan dirinya yang dahulu adalah seorang kernet angkot, namun dengan tekad yang kuat dan semangat belajar untuk menjadi lebih baik akhirnya beliau bisa keluar dari zonanya dan tumbuh menjadi politisi sukses.

Beliau menuturkan jika penyandang disabilitas pun punya potensi yang bisa dikembangkan, selama kondisi disabilitasnya ringan dan mampu berpikir dengan baik. Akan tetapi sejauh ini belum ada kelompok difabel yang ikut aktif di dalam kepengurusan partai. Hanya sesekali ada yang menjadi simpatisan partai ketika berkampanye. Politisi ini memandang bahwa mungkin saja para difabel ini masih ragu dan tidak percaya diri dengan kompetensi yang dimilikinya. Padahal jika saja mau mencoba, mungkin ada jalan ke depannya. Beliau menambahkan "kan kalau dari mereka ada yang jadi anggota DPRD, suara mereka jadi lebih didengar".

\section{Faktor-Faktor yang Mempengaruhi Partisipasi Disabilitas dalam Pilkada Kabupaten Kudus Tahun 2018}

KPUD Kabupaten Kudus mencatat jumlah penyandang disabilitas yang terdaftar sebagai DPT pada Pilkada tahun 2018 berjumlah 843 pemilih atau 0,131\% dari seluruh DPT di Kabupaten Kudus, yang terdiri dari disabilitas daksa, disabilitas netra, disabilitas rungu dan tuli, disabilitas mental (ODGJ), dan disabilitas lainnya. Meskipun jumlah ini masih sangat minim dan kita bisa mengatakan tingkat partisipasi ini rendah, tapi di sisi lain kita bisa melihat dengan kecamata bahwa masih ada keinginan dari kelompok disabilitas untuk turut berpartisipasi aktif dalam Pilkada dengan kondisi yang serba terbatas.

Partisipasi disabilitas dalam Pilkada Kabupaten Kudus tahun 2018 didukung oleh : a) sosialisasi Pilkada oleh KPUD kabupaten Kudus; b) peningkatan keterlibatan/partisipasi penyandang disabilitas dalam kegiatan pra maupun pasca pilkada yang diselenggarakan oleh KPUD Kudus dan Bawaslu Kudus, seperti mempersiapkan logistik pilkada, menjadi peserta debat terbuka calon bupati dan wakil bupati, menghadiri sosialisasi pengawasan partisipatif, dan kegiatan lainnya; c) Keberadaan sosial media dan internet saat ini juga turut berkontribusi memberika pengetahuan bagi disabilitas tentang tata cara pilkada serta bagaimana latar belakang, visi dan misi calon gubernur dan wakil gubernur serta calon bupati dan wakil bupati. Banyaknya informasi yang beredar di internet membantu kaum difabel untuk mendapatkan informasi, sehingga bisa menjadi pengetahuan pelaksanaan pilkada sekaligus menjadi bahan pertimbangan dalam menentukan pilihan. 
Sementara itu beberapa hambatan yang dialami oleh penyandang disabilitas dalam partisipasi Pilkada antara lain : a) kondisi disabilitas berat yang tidak memungkinkan mereka untuk menuju tempat pemungutan suara; b) sulitnya aksesibilitas menuju ke TPS. Tidak semua difabel mempunyai fasilitas kursi roda atau kendaraan yang sudah dimodifikasi; c) masih adanya TPS yang kurang ramah disabilitas. Misalnya TPS yang masih menggunakan ruangan kelas maupun gedung bertangga; d) Masih adanya penyandang difabel yang namanya tidak terdata sebagai Daftar Pemilih Tetap (DPT).

\section{Kesimpulan}

Partisipasi disabilitas dalam Pilkada Kabupaten Kudus tahun 2018 ini akan kita lihat dari bentuk partisipasi, faktor pendukung partisipasi dan penghambatnya partisipasi. Bentuk Partisipasi yang dilakukan oleh penyandang disabilitas pada Pilkada Kabupaten Kudus tahun 2018 yaitu : a) Mengikuti sosialisasi Pilkada yang dilaksanakan oleh KPUD Kabupaten Kudus baik di tingkat Kabupaten, kecamatan, desa, maupun antar lintas komunitas difabel; b) Mengikuti sosialisasi pengawasan pemilu yang dilaksanakan oleh Bawaslu kabupaten Kudus; c) Menghadiri debat terbuka calon bupati dan wakil bupati Kudus tahun 2018 di pendopo Kabupaten Kudus; d) Memberikan hak suaranya pada Pilkada Kabupaten Kudus Tahun 2018; e) Berpartipasi sebagai panitia penyelenggara pilkada di tingkat desa; dan f) Melakukan diskusi politik antar penyandang disabilitas dalam acara komunitas yang mereka adakan. Sebagai warga Negara Indonesia, penyandang disabilitas mempunyai hak yang sama di bidang politik. Sekecil apapun jumlah mereka, peminggiran terhadap kelompok ini dalam bidang politik adalah hal yang tidak dibenarkan.

\section{DAFTAR PUSTAKA}

Budiman, Hendra. 2015. Pilkada Tidak Langsung Dan Demokrasi Palsu. Yogyakarta: Pustaka Yustisia.

Dieye, Mar Abdoulaye. 2019. "Participation of Persons with Disabilities in Political and Public Life." UNDP. https://www.undp.org/speeches/participation-personsdisabilities-political-and-public-life.

Fadjar, Abdul Mukhtie. 2006. Hukum Konstitusi Dan Mahkamah Konstitusi. Jakarta: Konpress.

Fayomi, Oluyemi, and Grace Adebayo. 2017. "Political Participation and Political Citizenship."

https://www.researchgate.net/publication/323540493_Political_participation_and_ political_citizenship?enrichId=rgreq-e5fb428016872bbfcab28e9ca10c42baXXX\&enrichSource=Y292ZXJQYWdlOzMyMzU0MDQ5MztBUzo3NTM0ODIy 
MzU2NjY0MzRAMTU1NjY1NTU3MjIwMQ\%3D\%3D\&el=1_x_2\&_esc=public ationCoverPdf.

Guidelines on Promoting the Political Participation of Persons with Disabilities. 2019. https://www.osce.org/files/f/documents/b/6/414344.pdf.

"Jutaan Penyandang Disabilitas Absen Dalam Pemilu Dan Pilkada." 2018. BBC Indonesia.

https://www.bbc.com/indonesia/berita_indonesia/2015/01/150129_indonesia_difab el_pemilu (September 5, 2018).

Kusmawanto, Zuli, and Santi Nurjannah. 2021. "Strategi KPUD Lamongan Dalam Meningkatkan Partisipasi Pemilih Penyandang Disabilitas Di Kabupaten Lamongan Pada Pemilu Serentak 2019." Humanis 3(1). http://ejurnal.unisda.ac.id/index.php/Humanis/article/view/2316/1547.

"Lahirnya Undang-Undang Republik Indonesia Nomor 8 Tahun 2016 Dan UndangUndang Republik Indonesia Nomor 7 Tahun 2017 Bagi Penyandang Disabilitas.” 2017. KPUD DIY. http://diy.kpu.go.id/web/2017/11/15/lahirnya-undang-undangrepublik-indonesia-nomor-8-tahun-2016-dan-undang-undang-republik-indonesianomor-7-tahun-2017-bagi-penyandang-disabilitas/ (September 5, 2018).

Mohammad, Nazir. 1998. Metode Penelitian. Jakarta: Ghalia Indonesia.

Sholichah, Aulia, and Iman Nurchotimah. 2020. "The Forms of Political Participation in General Elections by Beginner Voters." Journal of Etika Demokrasi 5(2): 236-37. https://journal.unismuh.ac.id/index.php/jed/article/download/3440/2633.

Subekti, Tia. 2014. "Partisipasi Politik Masyarakat Dalam Pemilihan Umum (Studi Turn of Voter Dalam Pemilihan Umum Kepala Daerah Kabupaten Magetan Tahun 2013)." Journal and Governance and Policy 1(1): 5-22.

Surbakti, Ramlan. 2007. Memahami Ilmu Politik. Jakarta: PT. Gramedia Widisarana Indonesia.

Surwandono. 2017. Pemikiran Politik Islam: Metodologi, Pemikiran, Pelembagaan. Yogyakarta: CV. Komojoyo.

Undang-Undang Nomor 19 Tahun 2011 Tentang Pengesahan Hak-Hak Penyandang Disabilitas. 2011. ndonesia.

Undang-Undang Republik Indonesia Nomor 8 Tahun 2016 Tentang Penyandang Disabilitas. 


\section{Umi Qodarsasi}

